\title{
Clq metabolism in ulcerative colitis and Crohn's disease
}

\author{
B. J. POTter, H. J. F. HOdgSON,1 A. S. MEe, 2 AND D. P. JEWELl \\ From the Academic Department of Medicine, Royal Free Hospital, London
}

SUMmaRY The metabolism of pure radioiodine labelled Clq has been observed in five patients with ulcerative colitis, five patients with Crohn's disease, and in five control subjects. Both the fractional catabolic rate and the synthesis rate of Clq were increased in the five patients with Crohn's disease and in four of the five patients with ulcerative colitis. The fifth patient was in remission and had a normal synthesis rate. These results support the hypothesis that complement activation plays a role in the pathogenesis of these disease states and that the increased complement activation is primarily via the classical pathway.

Circulating immune complexes have been found in patients with active inflammatory bowel disease (Jewell and MacLennan, 1973; Doe et al., 1973; Mowbray et al., 1973; Ezer and Hayward, 1974). They are frequently present in high titre in patients with extraintestinal manifestations (Hodgson et al., 1977a) and may be involved in their pathogenesis. Although the role of immune complexes in the pathogenesis of mucosal lesions is not clearly defined, an experimental immune complex mediated colitis can be produced in rabbits which is histologically similar to human ulcerative colitis (Hodgson et al., 1978).

Hypercatabolism of the third component of complement, $\mathrm{C} 3$, has been demonstrated in patients with inflammatory bowel disease (Hodgson et al., 1977b) even though the serum concentrations are normal or raised (Ward and Eastwood, 1974; Hodgson et al., 1977c). This component can, however, be activated either through the classical pathway by immune complexes, or the alternative pathway by substances such as bacterial endotoxins (Mergenhagen et al., 1973). The aim of this study was therefore to investigate the catabolism of Clq, which is the subcomponent of the complement system that binds to immune complexes to activate the classical complement pathway.

${ }^{1}$ Present address: Royal Postgraduate Medical School, Ducane Road, London W.12.

2Present address: The Middlesex Hospital, Mortimer Street, London W.1.

Received for publication 25 May 1979.

\section{Methods}

\section{PATIENTS}

The subjects studied comprised five patients with ulcerative colitis and five patients with Crohn's disease. Details of these patients are given in Table 1. Diagnosis of ulcerative colitis and Crohn's disease was on the basis of clinical, radiological, and histological criteria. The severity of their disease was assessed according to the criteria of Truelove and Witts (1955) for ulcerative colitis and of de Dombal et al. (1974) for Crohn's disease. One patient with ulcerative colitis (E. McF) was in complete remission; five patients were on no treatment at the time of study and in the other five treatment was not altered immediately before or during the study. Five control subjects were also studied, four of whom were patients with non-inflammatory disorders (irritable colon syndrome, nutritional osteomalacia) and one healthy volunteer. The ages of the patients ranged from 24 to 70 years and that of the control subjects from 24 to 53 years. The Ethics Committee approved of the project and before each study began the informed consent and co-operation of the subject was obtained.

ISOLATION OF Clq

Pure, metabolically functional Clq was isolated from fresh human serum by the method of Reid et al. (1972) with minor modifications. The fresh human serum was obtained from a volunteer panel of donors at the Royal Free Hospital. The euglobulin fraction from 4 litres of serum was precipitated by dialysis against $0.02 \mathrm{M}$ sodium acetate buffer, $\mathrm{pH} 5 \cdot 5$ 
Table 1 Clinical details on patients studied

\begin{tabular}{|c|c|c|c|c|c|}
\hline & Sex & $\begin{array}{l}\text { Age } \\
(y r)\end{array}$ & Extent/site & Severity & Treatment (daily) \\
\hline $\begin{array}{l}\text { Ulcerative colitis } \\
\text { E.H. } \\
\text { A.K. } \\
\text { P.K. } \\
\text { E.McF. } \\
\text { D.W. }\end{array}$ & $\begin{array}{l}\mathbf{F} \\
\mathbf{M} \\
\mathbf{F} \\
\mathbf{F} \\
\mathbf{F}\end{array}$ & $\begin{array}{l}26 \\
70 \\
38 \\
48 \\
55\end{array}$ & $\begin{array}{l}\text { Distal } \\
\text { Total } \\
\text { Total } \\
\text { Distal } \\
\text { Distal }\end{array}$ & $\begin{array}{l}\text { Moderate } \\
\text { Moderate } \\
\text { Moderate } \\
\text { Remission } \\
\text { Moderate }\end{array}$ & $\begin{array}{l}\text { None } \\
\text { None } \\
\text { Sulphasalazine 2g } \\
\text { Sulphasalazine 2g } \\
\text { Sulphasalazine 2g }\end{array}$ \\
\hline $\begin{array}{l}\text { Crohn's disease } \\
\text { J.C. } \\
\text { L.E. } \\
\text { B.F. }\end{array}$ & $\begin{array}{l}\mathbf{F} \\
\mathbf{M} \\
\mathbf{F}\end{array}$ & $\begin{array}{l}24 \\
54 \\
27\end{array}$ & $\begin{array}{l}\text { Ileocolitis } \\
\text { Ileal } \\
\text { Ileocolitis }\end{array}$ & $\begin{array}{l}\text { Moderate } \\
\text { Moderate } \\
\text { Moderate }\end{array}$ & $\begin{array}{l}\text { Sulphasalazine } 2 \mathrm{~g} \\
\text { None } \\
\text { Prednisolone } 20 \mathrm{mg} \\
\text { Sulphasalazine } 2 \mathrm{~g}\end{array}$ \\
\hline $\begin{array}{l}\text { D.H. } \\
\text { G.S. }\end{array}$ & $\begin{array}{l}\mathbf{F} \\
\mathbf{M}\end{array}$ & $\begin{array}{l}41 \\
50\end{array}$ & $\begin{array}{l}\text { Ileal } \\
\text { Ileocolitis }\end{array}$ & $\begin{array}{l}\text { Mild } \\
\text { Severe }\end{array}$ & $\begin{array}{l}\text { None } \\
\text { None }\end{array}$ \\
\hline
\end{tabular}

and, after re-solution and high speed centrifugation to flotate contaminating lipid, it was subjected to ion-exchange chromatography on a $60 \mathrm{~cm} \times 64 \mathrm{~cm}^{2}$ column of DEAE-cellulose (Whatman DE52) equilibrated with $55 \mathrm{mmol}$ sodium phosphate buffer containing $1 \mathrm{mmol}$ EDTA, pH 7·4. The leading peak was concentrated by pressure ultrafiltration to $30 \mathrm{ml}$, dialysed against $56 \mathrm{mmol}$ sodium phosphate buffer containing $200 \mathrm{mmol}$ sodium chloride, pH $5 \cdot 2$ and eluted from a $90 \mathrm{~cm} \times 32 \mathrm{~cm}^{2}$ column of Sephadex G200 by upward flow. Again the first peak was concentrated to $30 \mathrm{ml}$ and dialysed against 230 mmol sodium acetate buffer, $\mathrm{pH} 5 \cdot 2$. The sample was loaded on to a $30 \mathrm{~cm} \times 4 \mathrm{~cm}^{2}$ column of CMcellulose (Whatman CM52) equilibrated with this buffer. After elution of the first peak, Clq was eluted using a linear salt gradient from the starting buffer to $230 \mathrm{mmol}$ sodium acetate, $\mathrm{pH} 5 \cdot 2$, containing 270 mmol sodium chloride. Clq activity was assessed by Ouchterlony analysis against anti-Clq antiserum (Hoechst) and the positive fractions pooled and concentrated by pressure ultrafiltration to $6-8 \mathrm{ml}$.

Protein concentration was estimated using $\mathrm{E}_{1 \mathrm{~cm}, 280 \mathrm{~nm}}^{1 \%}$ =6.82 (Reid et al., 1972).

All buffers were prepared in 'water for injection' (Travenol Laboratories) and contained either streptomycin sulphate $(100 \mathrm{mg} / \mathrm{l})$ and benzyl penicillin $\left(1 \times 10^{6}\right.$ units $\left./ 1\right)$ or gentamycin sulphate $(80 \mathrm{mg} / \mathrm{l})$ and the sodium salt of ampicillin $(250 \mathrm{mg} / \mathrm{l})$. All apparatus and buffers were either autoclaved or sterilised using commercial sterilising agents.

Protein purity was assessed by polyacrylamide gel electrophoresis, isoelectric focusing, analytical ultracentrifugation and its reaction to multispecific antisera (Hoechst). Biological activity was assessed by its incorporation into the Clq, r, s complex. Aliquots of plasma samples, obtained from subjects injected with ${ }^{125} \mathrm{I}-\mathrm{Clq}$, were subjected to either gel filtration on a $90 \mathrm{~cm} \times 8 \mathrm{~cm}^{2}$ Sepharose $6 \mathrm{~B}$ column or sucrose density gradient ultracentrifugation on a $10-40 \% \mathrm{wt} / \mathrm{wt}$ phosphate buffered sucrose gradient. Gradients were prepared by the method of Britten and Roberts (1960) and centrifuged at 27000 $\mathrm{rev} / \mathrm{min}$ in a $3 \times 25 \mathrm{ml}$ swing-out rotor (MSE). In both cases fractions were tested for radioactivity and Cls activity against specific anti-Cls antiserum (Hoechst).

\section{RADIOIODINE LABELLING OF Clq}

Clq was labelled with ${ }^{125} I$ by the method of McConahey and Dixon (1966). Five to six milligrams of Clq in $3 \mathrm{ml} 100 \mathrm{mM}$ sodium phosphate buffer containing $1 \mathrm{mM}$ EDTA, pH 7.0, was stirred in a beaker on an ice bath. To this was added $1 \mathrm{mCi}$ of carrier free $\mathrm{Na}^{125} \mathrm{I}$ (Radiochemical Centre, Amersham) followed by $50 \mu \mathrm{g}$ chloramine-T in 0.5 $\mathrm{ml}$ pyrogen-free distilled water. After five minutes the reaction was stopped by the addition of $60 \mu \mathrm{g}$ sodium metabisulphite in $0.6 \mathrm{ml}$. The mixture was allowed to stand for an additional 10 minutes before being exhaustively dialysed, first against $100 \mathrm{mmol}$ sodium phosphate buffer containing $1 \mathrm{mmol}$ EDTA, pH 7.0 and then against $0.85 \%$ sodium chloride containing $1 \mathrm{mmol}$ EDTA (tetrasodium salt), in order to remove unbound ${ }^{125} \mathrm{I}$. The ${ }^{125} \mathrm{I}-\mathrm{Clq}$ was then centrifuged at $85000 \mathrm{~g}\left(\mathrm{r}_{\mathrm{av}}\right)$ and $2^{\circ} \mathrm{C}$ for $1 \frac{1}{2}$ hours to remove aggregates and any bacterial contamination.

One aliquot of each labelled batch was tested for pyrogens by injection into rabbits (Consultox Laboratories, Ealing). Batches were used only if they met the acceptable standards of negligible pyrogenicity and bacterial contamination as laid down in the European Pharmacopoeia (1971).

\section{EXPERIMENTAL PROCEDURE}

Potassium iodide (30 mg twice daily) was administered to subjects 24 hours before the start of the study and then for seven days. After centrifugation to remove aggregates, weighed quantities of ${ }^{125} \mathrm{I}-\mathrm{Clq}$ 
were injected intravenously together with a weighed quantity of a solution of ${ }^{131} \mathrm{I}$ human serum albumin (Radiochemical Centre, Amersham). The total dose of radioactivity was less than $25 \mu \mathrm{Ci}$.

Plasma samples were taken at five, 15, 30, and 60 minutes after injection, at two hours, four hours, eight hours, and thereafter twice daily for six days. The total volume of urine passed during the study was collected in 24 hour aliquots and, for the patients only, stool collections were also made. Two millilitre aliquots of the plasma and $5 \mathrm{ml}$ aliquots of the urine were counted in an LKB 1280 ultragamma counter. The ${ }^{125} \mathrm{I}$ counts were corrected for crossover from the ${ }^{131}$ I channel. The faeces were weighed, made up to a constant weight with water, and homogenised with a blender: $10 \mathrm{ml}$ aliquots were counted. Two millilitre and $5 \mathrm{ml}$ aliquots of standard solution of the injected proteins made up in $0.85 \%$ saline containing Tween 80 were also counted.

Serum Clq concentrations were determined by a single radial immunodiffusion (Mancini et al., 1965) into $1 \%$ phosphate buffered agarose, $\mathrm{pH} 7 \cdot 2$, containing anti-human $\mathrm{Clq}$ antiserum (Hoechst). Diffusion was allowed to go to completion (approximately 60 hours). Under these conditions it was found unnecessary to incorporate EDTA into the buffered agarose. Standards were prepared from purified freeze-dried Clq. Serum albumin concentrations were determined colorimetrically using bromocresol green (Doumas et al., 1971). At least five separate determinations of the serum protein concentrations were made throughout each study. In no case did the serum concentrations vary significantly.

\section{ANALYSIS OF DATA}

The plasma of radioactivity disappearance curves were analysed by the multiexponential analysis technique of Matthews (1957). Best fit curve stripping for two and three exponentials was achieved using a CDC 7600 computer (University College, London). The plasma volumes were estimated by extrapolating to zero time. Fractional catabolic
Table 3 Comparison of fractional catabolic rates obtained for control subjects by three different methods

\begin{tabular}{|c|c|c|c|}
\hline & $\begin{array}{l}\text { Multiexponential } \\
\text { analysis } \\
(\% \text { IV pool/h) }\end{array}$ & $\begin{array}{l}\text { Urine: plasma } \\
\text { ratio } \\
(\% \text { IV pool/h) }\end{array}$ & $\begin{array}{l}\text { Integral } \\
\text { analysis } \\
(\% \text { IV pool/h) }\end{array}$ \\
\hline $\begin{array}{l}1 \\
2 \\
3 \\
4 \\
5 \\
\text { Mean } \pm \text { SEM }\end{array}$ & $\begin{array}{l}2 \cdot 85 \\
1.92 \\
2 \cdot 08 \\
2 \cdot 96 \\
1 \cdot 88 \\
2 \cdot 34 \pm 0.23\end{array}$ & $\begin{array}{l}2 \cdot 48 \\
1 \cdot 86 \\
2 \cdot 31 \\
3 \cdot 39 \\
2 \cdot 92 \\
2 \cdot 59 \pm 0.26\end{array}$ & $\begin{array}{l}2 \cdot 67 \\
1 \cdot 79 \\
2 \cdot 73 \\
2 \cdot 03 \\
1.59 \\
2 \cdot 31 \pm 0.21\end{array}$ \\
\hline
\end{tabular}

rates (FCRs) were also determined using the integrated rate equations of Nosslin (1973) and the metabolic clearance of Berson and Yalow (1957). In the patient group, faecal counts were included in the calculation of metabolic clearance.

\section{Results}

The isolated Clq was pure as judged by polyacrylamide gel electrophoresis, immunoelectrophoresis, and analytical ultracentrifugation. Biological activity was indicated by density gradient ultracentrifugation and gel filtration studies which demonstrated that, within 15 minutes of injection, over $95 \%$ of the ${ }^{125} \mathrm{I}$-Clq had been incorporated into the macromolecular $\mathrm{Cl}$ complex. The radioactivity was associated with the 19S fraction in which Cls activity was also demonstrated by immunodiffusion. When Clq was not incorporated into the Clqrs complex, as occurred on short-term in vitro incubation with normal human serum $\left(30\right.$ minutes at $\left.37^{\circ} \mathrm{C}\right)$, the radioactivity remained associated with the $11 \mathrm{~S}$ fraction, corresponding to the sedimentation coefficient of the Clq subcomponent.

The fractional catabolic rates (FCRs) based on multiexponential analysis obtained for the control subjects are given in Table 2 . The mean for the group was $2.34 \pm 0.23 \%$ IV pool/hour. There was no significant difference in the values obtained by stripping two or three exponentials. Metabolic clearance data $(\mathrm{U} / \mathrm{P})$ from all of the control subjects did not vary significantly from the mean fractional catabolic

Table 2 Clq metabolism in control subjects

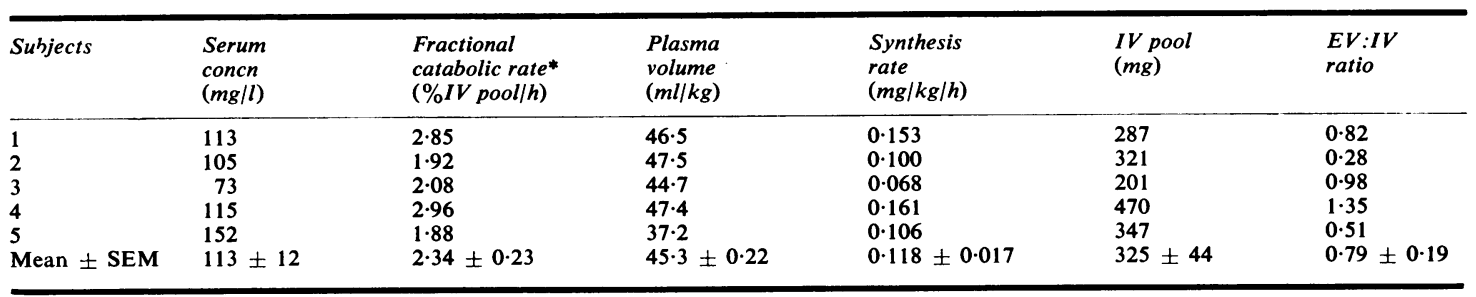

*Based on multiexponential analysis. 


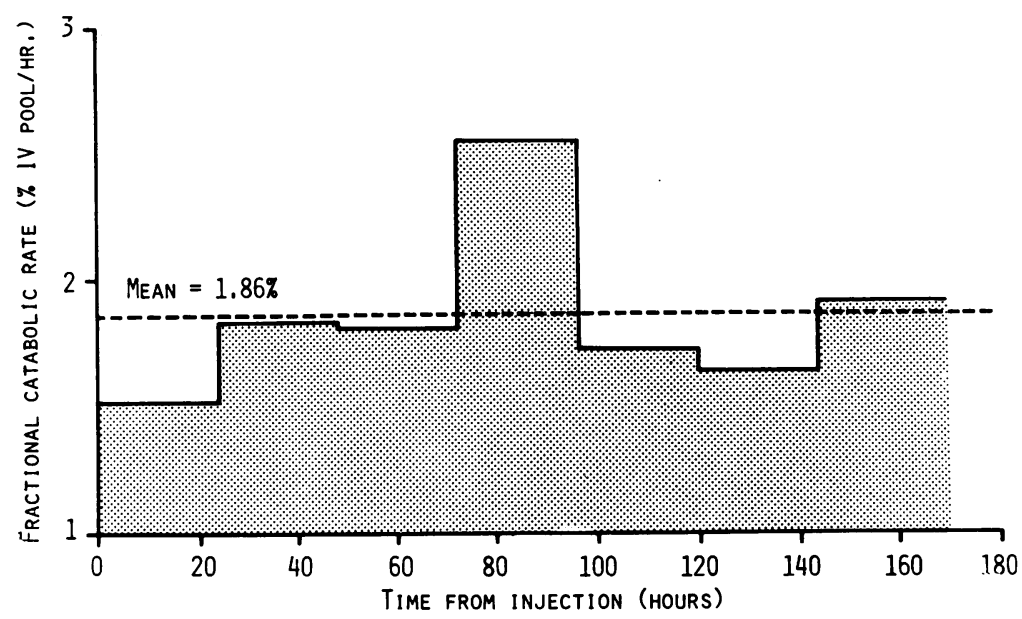

Fig. 1 Serial urine: plasma radioactivity ratios in a study of ${ }^{125} \mathrm{I}$-Clq metabolism in a control subject

rates throughout the course of the study and were in good agreement with the values obtained from multiexponential analysis and the integrated rate equation. A comparison of the fractional catabolic rates obtained by these methods may be seen in Table 3 and a typical example of $U / P$ values is shown in Fig. 1.

The ${ }^{125}$ I-Clq plasma disappearance curves for the

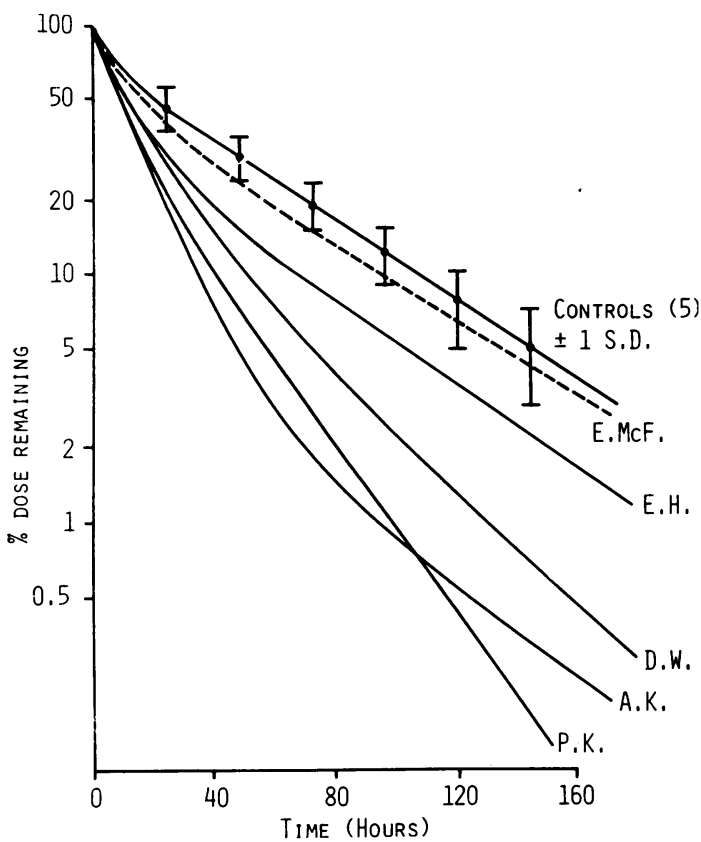

Fig 2 Plasma disappearance curves of ${ }^{125} \mathrm{I}$-CIq after intravenous injection into five patients with ulcerative colitis. The mean for the control subjects $( \pm 1 S D)$ is also given for comparison.

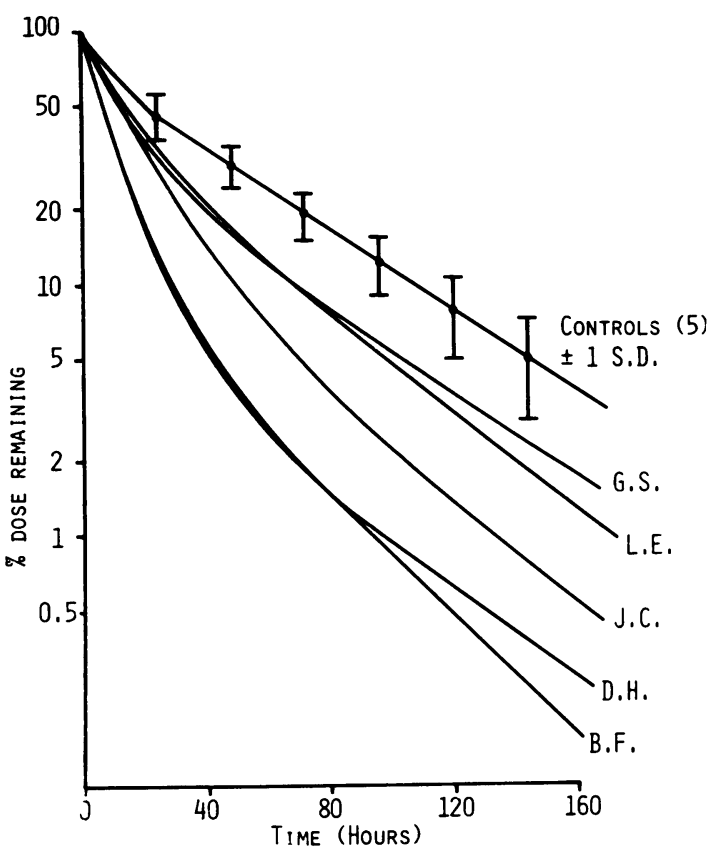

Fig. 3 Plasma disappearance curves of ${ }^{125} \mathrm{I}$-CIq after intravenous injection into five patients with Crohn's disease. The mean for the control subjects $( \pm 1 S D)$ is also given for comparison.

patients with ulcerative colitis are shown in Fig. 2 and those for patients with Crohn's disease in Fig. 3. In both the mean plasma disappearance curves for the control subjects $( \pm 1 \mathrm{SD})$ is given for comparison. For the five patients with Crohn's disease there was an accelerated disappearance of the labelled protein from the plasma. This was also true of the four patients with active ulcerative colitis, but subject 


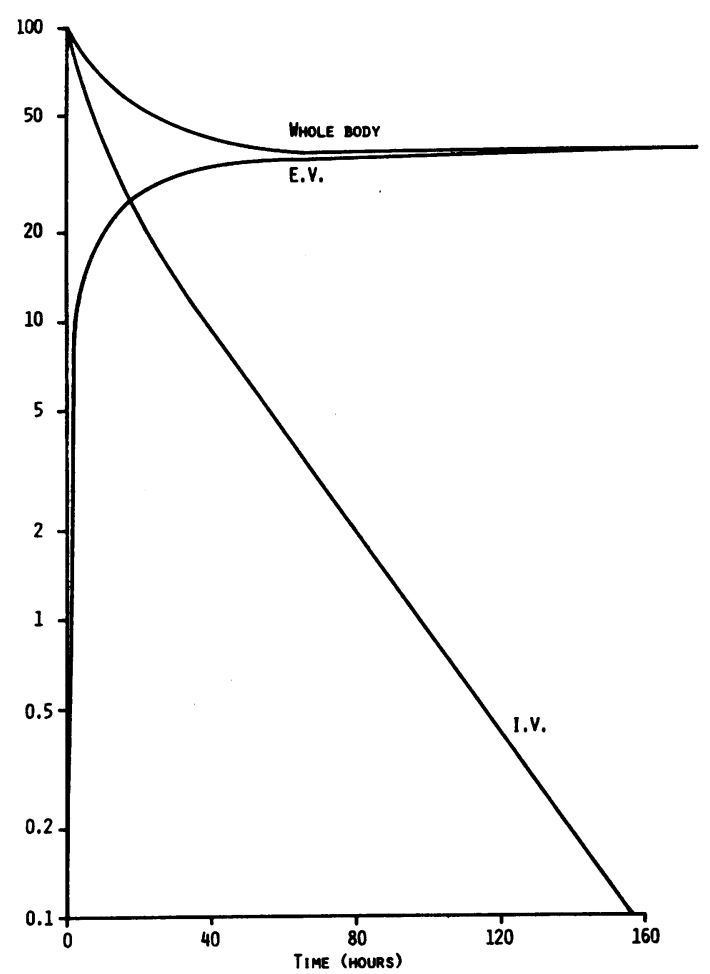

Fig. 4 Retention curves of ${ }^{125} \mathrm{I}-\mathrm{CI} q$ injected into a patient with ulcerative colitis (subject P.K.).

E. McF., who was in remission at the time of the study, showed a normal plasma disappearance rate. Figures 4 and 5 show the ${ }^{125} \mathrm{I}-\mathrm{Clq}$ retention curves for a patient with active ulcerative colitis (P.K.) and for a patient with Crohn's disease (L.E.). It will be seen that, once equilibrium has occurred between the plasma and the extravascular compartment, the rate of disappearance from the extravascular space is slower than that from the plasma. This therefore suggests that there is sequestration of $\mathrm{Clq}$ in an extravascular compartment.

The fractional catabolic rates for ${ }^{125} \mathrm{I}-\mathrm{Clq}$ calcu-

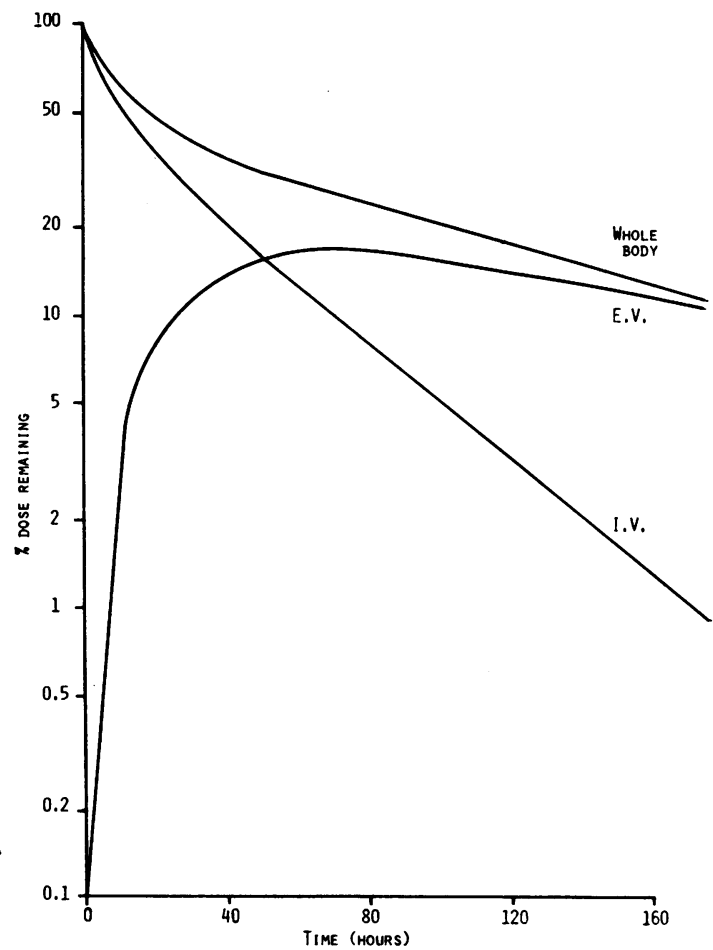

Fig. 5 Retention curves of ${ }^{125} \mathrm{I}$-CIq injected into a patient with Crohn's disease (subject L.E.).

Table 4 Clq metabolism in patients with ulcerative colitis and Crohn's disease

\begin{tabular}{|c|c|c|c|c|c|c|}
\hline & $\begin{array}{l}\text { Serum } \\
\text { concentration } \\
(m g / l)\end{array}$ & $\begin{array}{l}\text { Fractional } \\
\text { catabolic rate* } \\
(\% \text { IV pool/h) }\end{array}$ & $\begin{array}{l}\text { Plasma } \\
\text { volume } \\
(\mathrm{ml} / \mathrm{kg})\end{array}$ & $\begin{array}{l}\text { Synthesis } \\
\text { rate } \\
(\mathrm{mg} / \mathrm{kg} / \mathrm{h})\end{array}$ & $\begin{array}{c}I V \text { pool } \\
(\mathbf{m g})\end{array}$ & $\begin{array}{l}E V: I V \\
\text { ratio }\end{array}$ \\
\hline 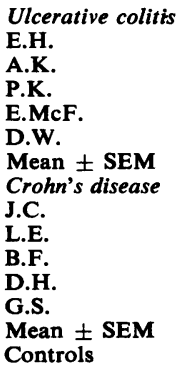 & $\begin{array}{r}131 \\
90 \\
99 \\
120 \\
81 \\
104 \pm 9 \\
167 \\
148 \\
148 \\
82 \\
77 \\
124 \pm 19 \\
113 \pm 12\end{array}$ & $\begin{array}{l}3.50 \\
7.81 \\
6 \cdot 11 \\
2 \cdot 71 \\
4.66 \\
4.96 \pm 0.91 \\
5.04 \\
3.81 \\
8.99 \\
8.44 \\
3.67 \\
5.99 \pm 1.14 \\
2.34 \pm 0.23\end{array}$ & $\begin{array}{l}39 \cdot 8 \\
30 \cdot 4 \\
51 \cdot 8 \\
30 \cdot 7 \\
36 \cdot 9 \\
37 \cdot 9 \pm 3.9 \\
35 \cdot 7 \\
75 \cdot 7 \\
37 \cdot 9 \\
48 \cdot 1 \\
97 \cdot 1 \\
58.9 \pm 11.9 \\
45 \cdot 3 \pm 2.2\end{array}$ & $\begin{array}{l}0 \cdot 182 \\
0 \cdot 214 \\
0 \cdot 313 \\
0 \cdot 100 \\
0 \cdot 139 \\
0 \cdot 190 \pm 0.036 \\
0 \cdot 300 \\
0 \cdot 427 \\
0 \cdot 504 \\
0 \cdot 333 \\
0 \cdot 274 \\
0.368 \pm 0.043 \\
0 \cdot 118 \pm 0.017\end{array}$ & $\begin{array}{l}381 \\
144 \\
267 \\
169 \\
210 \\
234 \pm 42 \\
315 \\
543 \\
335 \\
187 \\
417 \\
359 \pm 59 \\
325 \pm 44\end{array}$ & $\begin{array}{l}0.62 \\
0.40 \\
0.62 \\
1.90 \\
0.88 \\
0.88 \pm 0.27 \\
0.23 \\
1.29 \\
2.28 \\
3.97 \\
1.07 \\
1.77 \pm 0.64 \\
0.79 \pm 0.19\end{array}$ \\
\hline
\end{tabular}


Table 5 Albumin metabolism in control subjects in patients with inflammatory bowel disease

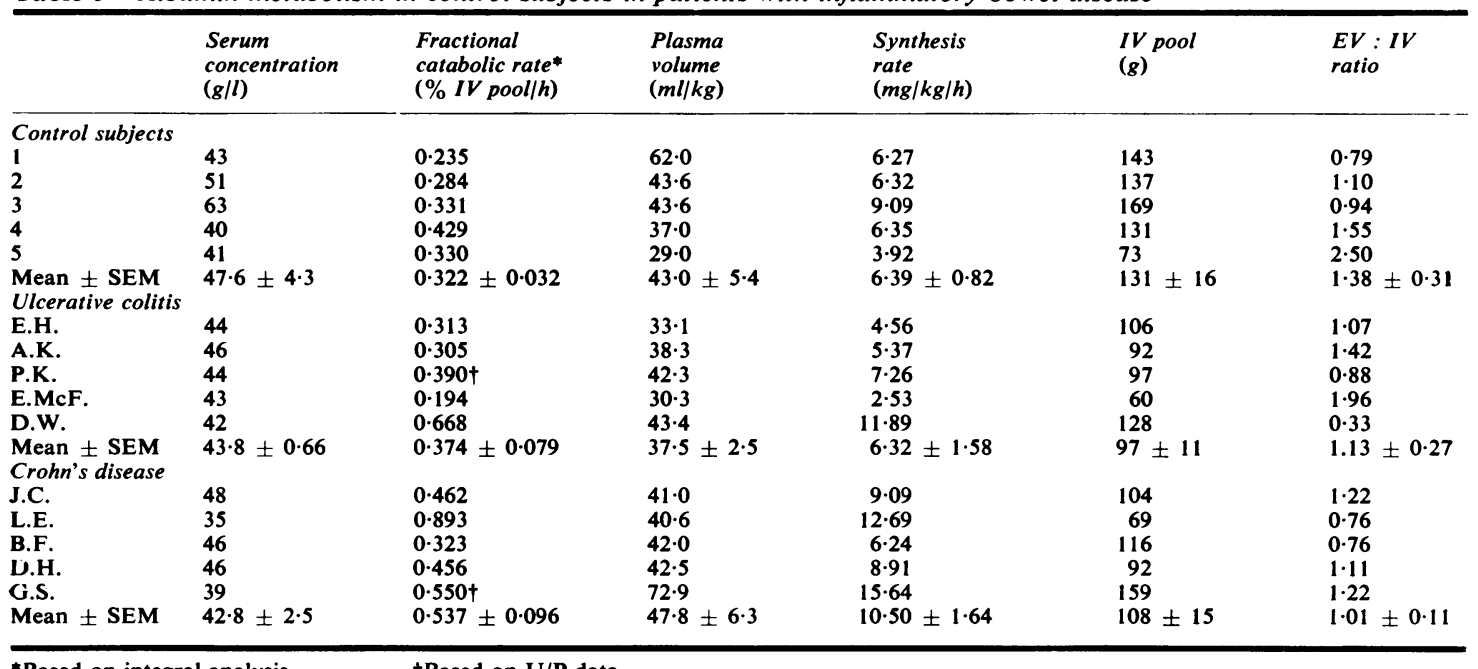

*Based on integral analysis.

+Based on U/P data.

lated from these curves using multiexponential analysis are shown in Table 4 . Similar data for the catabolism of albumin are given in Table 5. Although there is no significant difference in the serum $\mathrm{Clq}$ concentrations, the fractional catabolic rates and synthesis rates in nearly every case are markedly above those for the control subjects: the exception being the patient in remission at the time of the study (E. McF.). The accelerated catabolism cannot be accounted for by loss into the gastrointestinal tract. Table 6 shows the percentage of the injected dose lost over the first five days of the patient studies. In only one case (B.F.) did this exceed $3 \%$.

The associated albumin data for these patients show no significant difference in albumin metabolism for the patients with ulcerative colitis compared with the control subjects, but a marked rise in those with Crohn's disease.

Table 6 Percentage loss of injected dose into gastrointestinal tract over first five days

\begin{tabular}{lcl}
\hline Ulcerative colitis & $125 I-C l q$ & 181 I-HSA \\
\hline E.H. & 0.238 & 0.116 \\
A.K. & 0.829 & 2.081 \\
P.K. & 1.846 & 3.454 \\
E. McF. & ND & ND \\
D.W. & - & - \\
Crohn's disease & 0.528 & 1.060 \\
J.C. & 3.093 & 1.100 \\
L.E. & $24.793^{*}$ & 6.086 \\
B.F. & 0.338 & 1.237 \\
D.H. & 0.970 & 1.281 \\
G.S. & & \\
\hline
\end{tabular}

* Sixteen per cent lost on day 1

\section{Discussion}

The present studies have shown that the metabolism of Clq is increased in inflammatory bowel disease. Although protein turnover studies are subject to many errors, it seems probable that this is a real finding. The data for Clq metabolism in control subjects are in good agreement with those of Kohler and Müller-Eberhard (1972). The ${ }^{125} \mathrm{I}-\mathrm{Clq}$ injected appeared biologically active, as it was rapidly incorporated into the Clqrs complex. There was no evidence from the metabolic clearance data of a rapid excretion of ${ }^{125} \mathrm{I}$ within the first 36 hours, as would have occurred if denatured protein had been injected. The same batches of protein that showed normal catabolism in controls showed increased catabolism in patients with inflammatory bowel disease.

An interesting finding was the lack of in vitro incorporation of $\mathrm{Clq}$ into the $\mathrm{Cl}$ complex compared with the rapid incorporation seen in vivo and it seems likely that, once the subunits are synthesised and released, complex formation occurs instantaneously. Our in vitro findings suggest that the complex, once formed, is stable and little exchange takes place with exogenous Clq.

A possible explanation for the increased catabolism of $\mathrm{Clq}$ is faecal loss of the injected protein, as patients with active inflammatory bowel disease may lose protein by this route. The faecal excretion of ${ }^{125} \mathrm{I}$-Clq in the patients studied (Table 6), however, cannot explain the increased catabolism, except in one patient, even though the losses may be an underestimate as the injected protein was labelled 
with ${ }^{125} \mathrm{I}$ (Waldmann, 1970). It is also unlikely that we are merely recording a generalised increase in protein turnover, as in one group of patients (ulcerative colitis) raised Clq catabolism was seen with normal albumin turnover. In one patient, who was in remission, Clq metabolism was similar to the control subjects, which suggests that hypercatabolism occurs only in active disease. Obviously more patients in remission should be studied to confirm this, but it is difficult to admit well patients for metabolic studies when hospital admission is often a frequent event in the natural history of their disease.

The divergence between EV and IV distribution of Clq over the period of study in our patients is similar to that found by Kohler and MüllerEberhard (1972) in patients with hypogammaglobulinaemia and in two patients with myeloma. Similar $\mathrm{EV}$ accumulation of $\mathrm{C} 3$ has been observed in patients with inflammatory bowel disease (Hodgson et al., 1977b). These findings suggest retention of label within the EV compartment. This may occur as a result of increase in capillary permeability or of specific fixation of complement components at an EV site. In patients with inflammatory bowel disease it is possible that both mechanisms are operating within the inflamed mucosa.

Immunoglobulin production is greatly increased in the diseased intestine of these patients (McClelland et al., 1976) and some of this immunoglobulin has antibody specificity for bacterial antigens (Monteiro et al., 1971). It is highly probable, therefore, that the antigen-antibody reactions are occurring within the diseased mucosa with subsequent activation of complement via the classical pathway. The present studies do not exclude activation of the alternative pathway by such factors as endotoxin and $\operatorname{IgA}$, nor do they rule out activation of the classical pathway by factors such as proteolytic enzymes and bacterial products. Nevertheless, the demonstration of $\mathrm{Clq}$ activation in patients with inflammatory bowel disease supports the hypothesis that antigenantibody reactions are involved in the pathogenesis of mucosal inflammation.

\section{References}

Berson, S. A., and Yalow, R. S. (1957). Distribution and metabolism of $\mathrm{I}^{131}$-labelled proteins in man. Federation Proceedings, 16, 135-185.

Britten, R. J., and Roberts, R. B. (1960). High resolution density gradient sedimentation analysis. Science, 131, 32-33.

De Dombal, F. T., Burton, I. L., Clamp, S. E., and Goligher, J. C. (1974). Short-term course and prognosis of Crohn's disease. Gut, 15, 435-443.
Doe, W. F., Booth, C. C., and Brown, D. L. (1973). Evidence for complement-binding immune complexes in adult coeliac disease, Crohn's disease and ulcerative colitis. Lanct, 1, 402-403.

Doumas, B. T., Ard Watson, W., and Biggs, H. G. (1971). Albumin standards and the measurement of serum albumin with bromcresol green. Clinica Chimica Acta, 31, 87-96.

European Pharmacopoeia (1971). Volume 11, pp. 58-60. Published under the direction of the Council of Europe Maison-neuve S.A.: Sainte-Ruffine, France.

Ezer, G., and Hayward, A. R. (1974). Inhibition of complement dependent lymphocyte rosette formation: a possible test for activated complement products. European Journal of Immunology, 4, 148-150.

Hodgson, H. J. F., Potter, B. J., and Jewell, D. P. (1977a). Immune complexes in ulcerative colitis and Crohn's disease. Clinical and Experimental Immunology, 29, 187-196.

Hodgson, H. J. F., Potter, B. J., and Jewell. D. P. (1977b). C3 metabolism in ulcerative colitis and Crohn's disease. Clinical and Experimental Immunology, 23, 490-495.

Hodgson, H. J. F., Potter, B. J., and Jewell, D. P. (1977c). Humoral immune system in inflammatory bowel disease: I. Complement levels. Gut, 18, 749-753.

Hodgson, H. J. F. , Potter, B. J., Skinner, J., and Jewell, D. P. (1978). Immune-complex mediated colitis in rabbits, an experimental model. Gut, 19, 225-232.

Jewell, D. P., and MacLennan, I. C. M. (1973). Circulating immune complexes in inflammatory bowel disease. Clinical and Experimental Immunology, 14, 219-226.

Kohler, P. F., and Müller-Eberhard, H. J. (1972). Metabolism of human Clq. Studies in hypergammaglobulinemia, myeloma, and systemic lupus erythematosus. Journal of Clinical Investigation, 51, 868-875.

McClelland, D. B. L., Shearman, D. J. C., Lai A Fat, R. F. M., and van Furth, R. (1976). In vitro synthesis of immunoglobulins, secretory component, complement and lysosozyme by human gastrointestinal tissues. II. Pathological tissues. Clinical and Experimental Immunology, 23, 20-27.

McConahey, P. J., and Dixon, F. J. (1966). A method of trace iodination of proteins for immunologic studies. International Archives of Allergy and Applied Immunology, 29, 185-189.

Mancini, G., Carbonara, A. O., and Heremans, J. F. (1965). Immunochemical quantitation of antigens by single radial immunodiffusion. Immunochemistry, 2 , 235-254.

Matthews, C. M. E. (1957). The theory of tracer experiments with ${ }^{131}$ I-labelled plasma proteins. Physics in Medicine and Biology, 2, 36-53.

Mergenhagen, S. E., Snyderman, R., and Phillips, J. K. (1973). Activation of complement by endotoxin. Journal of Infectious Diseases, 128, 586-590.

Monteiro, E., Fussey, J. Shiner, M., Drasar, B. S., and Allison, A. C. (1971). Antibacterial antibodies in rectal and colonic mucosa in ulcerative colitis. Lancet, 1, 249-251.

Mowbray, J. F., Holborow, E. J., Hoffbrand, A. V., Seah, P. P., and Fry, L. (1973). Circulating immune 
complexes in dermatitis herpetiformis. Lancet, 1, 400-402.

Nosslin, B. (1973). Analysis of disappearance time-curves after single injection of labelled proteins. In Protein Turnover, pp. 113-130. Ciba Foundation Symposia; New Series 9. Edited by G. E. W. Wolstenholme and M. O'Connor. Associated Scientific Publishers: Amsterdam.

Reid, K. B. M., Lowe, D. M., and Porter, R. F. (1972). Isolation and characterization of Clq, a subcomponent of the first component of complement, from human and rabbit serum. Biochemistry Journal, 130, 749-763.

Truelove, S. C., and Witts, L. J. (1955). Cortisone in ulcerative colitis: final report on a therapeutic trial. British Medical Journal, 2, 1041-1048.

Waldmann, T. A. (1970). Protein losing enteropathy. In Modern Trends in Gastroenterology, 4, pp. 125-142. Edited by W. I. Card and B. Creamer. Butterworths: London.

Ward, M., and Eastwood, M. A. (1974). Serum complement components $\mathrm{C} 3$ and $\mathrm{C} 4$ in inflammatory bowel disease. (Abstract). Gut, 15, 835. 